\title{
Innovation for sustainable urban tourism: Some thoughts on best practice*
}

\author{
Noel Scott** \\ Chris Cooper***
}

Summary: 1. Introduction; 2. Sustainable urban tourism - what is this?; 3. Conclusions.

SumÁRIo: 1. Introdução; 2. O que é turismo urbano sustentável?; 3. Conclusões.

KEY WORDs: destination management; sustainable urban tourism; networks; innovation.

Palavras-chave: gestão dos destinos turísticos; turismo urbano sustentável; redes; inovação.

This paper examines a series of strategic initiatives that have been undertaken by Tourism Queensland (TQ), a State Tourism Organization in Australia, to develop tourism and in particular to develop networks in tourism destinations. This paper firstly examines the nature of sustainable urban tourism (SUT) and discusses approaches to defining it. It suggests that developing SUT requires a generic approach to improving sustainable tourism operations amongst all suppliers in an urban area. Further, this approach suggests that best practice in marketing and policy development can be adopted to attract tourists to a SUT destination and examples of this approach are provided.

Inovação para o turismo urbano sustentável: algumas reflexões sobre as melhores práticas

Este artigo analisa uma série de iniciativas estratégicas que têm sido desenvolvidas pelo Turismo de Queensland (TQ), uma organização estatal de turismo, na Austrá-

\footnotetext{
* Article received in May e accepted in Aug. 2010.

** PhD. Associate professor, School of Tourism, The University of Queensland. GPN 39A, St. Lucia Campus, 4072, Brisbane, Australia. E-mail: noel.scott@uq.edu.au.

*** PhD. Dean/Pro Vice-Chancellor, Faculty of Business, Oxford Brookes University, Headington Campus, Gipsy Lane, Oxford OX3 OBP, United Kingdom. E-mail: ccooper@brookes.ac.uk.
} 
lia, para desenvolver o turismo e, principalmente, as redes de destinos turísticos. Este artigo, em primeiro lugar, examina a natureza do turismo urbano sustentável (SUT) e discute as abordagens para defini-la. Sugere que o desenvolvimento SUT requer uma abordagem genérica para melhorar as operações de turismo sustentável, entre todos os fornecedores em uma área urbana. Além disso, sugere que as melhores práticas em marketing e desenvolvimento de políticas podem ser adotadas para atrair os turistas para um destino SUT e são fornecidos exemplos dessa abordagem.

\section{Introduction}

Around the world, tourism as a category of private expenditure has grown rapidly over the past 60 years. These changes have been driven by factors such as technological innovations, like the introduction of pressurized jet passenger aircraft in the 1960s; rapid economic growth and increases in disposable income, most recently in Asian countries; and increasing competition between countries and destinations leading to increasing tourism marketing expenditure. Today, tourism is estimated to make up $6 \%$ of global exports of goods and services (WTO, 2009).

As may be expected, the types of tourism experienced by travelers have evolved over these 60 years. Mass coastal tourism such as that found in Spain in the 60s and 70s has given way to a more sophisticated and differentiated set of product markets. Thus we speak today of types of tourism such as ecotourism, urban tourism, and heritage tourism; that grow and decline in popularity due to numerous factors within the external environment (see Dwyer et al., 2009, for a discussion of these factors). One external factor of critical importance that has emerged over the past decade is the recognition of the impact of human activity on the environment through pollution, and the consequent effects such as global warming. The effect of these concerns has led to evolution of new types of tourism emphasizing sustainability, such as ecotourism, sustainable tourism and sustainable urban tourism (SUT). But what do we mean by a type of tourism?

\section{Sustainable urban tourism - what is this?}

To answer this question, we must first discuss the nature of tourism and its variants. Types of tourism such as ecotourism are often considered forms of special interest tourism (Weiler and Hall, 1992). According to Read (1980:195) 
special interest travel is travel for people who are going somewhere because they have a particular interest that can be pursued in a particular region or at a particular destination. It is the hub around which the total travel experience is planned and developed.

While subject to criticism concerning differentiation of motivation and activity and subject to over counting (McKercher and Chan, 2005), there appears to be a broad consensus that motivations for travel are becoming more specific, and that in many countries there is a trend away from leisure mass tourism and towards travelling for specific reasons, interests or activities. A type of tourism then emphasizes some unique activity(ies) and interests, while sharing many common travel components, such as the use of hotels or airplanes, in essence creating a number of overlapping product markets (Day, Shocker, and Srivastava, 1979). Thus tourism product types (termed here product markets) share some common components such as accommodation, transport and attractions, but differ in the particular variant of these components included in the product bundle and thus forming separate product markets.

Product markets are an important unit of analysis within the strategic marketing literature and have been used in the examination of a number of critical questions, such as whether market boundaries are distinct and stable or shifting and overlapping (Viswanathan and Childers, 1999), and how new products diffuse into new markets (Rosa, Porac, Spanjol, and Saxon, 1999). Product markets within a product class have been used to study how markets evolve and grow (Lambkin and Day, 1989). The tourism literature, however, generally defines product types based on traveler segments only, as can be seen from the many papers discussing traveler profiles or the characteristics of travel segments (Frochot and Morrison, 2000; Galloway et al., 2008; Jurowski and Reich, 2000), but not examining the characteristics of the network of suppliers who jointly meet the needs of these groupings of tourists. The concept of a product market combines the customers and suppliers, and is jointly constructed by customers and suppliers (Vargo and Lusch, 2004; 2008) as shown in figure 1 . Clearly product markets evolve over time and may be shaped by the actions of suppliers (Scott, 2003).

At question in this paper is how different SUT is from other tourism product markets now and also how it may develop in the future. We may consider two possibilities; firstly that SUT involves many of the same suppliers as provide services to non-SUT travelers; or secondly that many of the suppliers of SUT services are different and cater to a distinct group of customers. There 
is little information to validate either possibility, but in the author's experience, in general, SUT primarily involves the same services as other types of tourism. There are no specialist airlines that are distinctly more sustainable than others, and travelers jointly are transported in the same plane, although some traveler may choose to offset their carbon emissions. There is more differentiation in the accommodation services provided, with eco-aware/lower resource use hotels available in some destinations. The largest variation in the sustainability of the suppliers involved in SUT is in those offering discretionary destination activities such as tours and attractions. Thus we may conclude that SUT today is mostly differentiated from other forms of tourism by the activities undertaken and the services offered in the destination. It should also be noted that the energy used to transport tourists to a particular destination produces a significant component of total carbon pollution from a trip (Gossling and Peeters, 2007; Kelly and Williams, 2007). This means that SUT produces greenhouse gasses and other pollution but somewhat less than other types, and with options for mitigation of these effects through carbon offsets.

Figure 1

\section{Product markets}

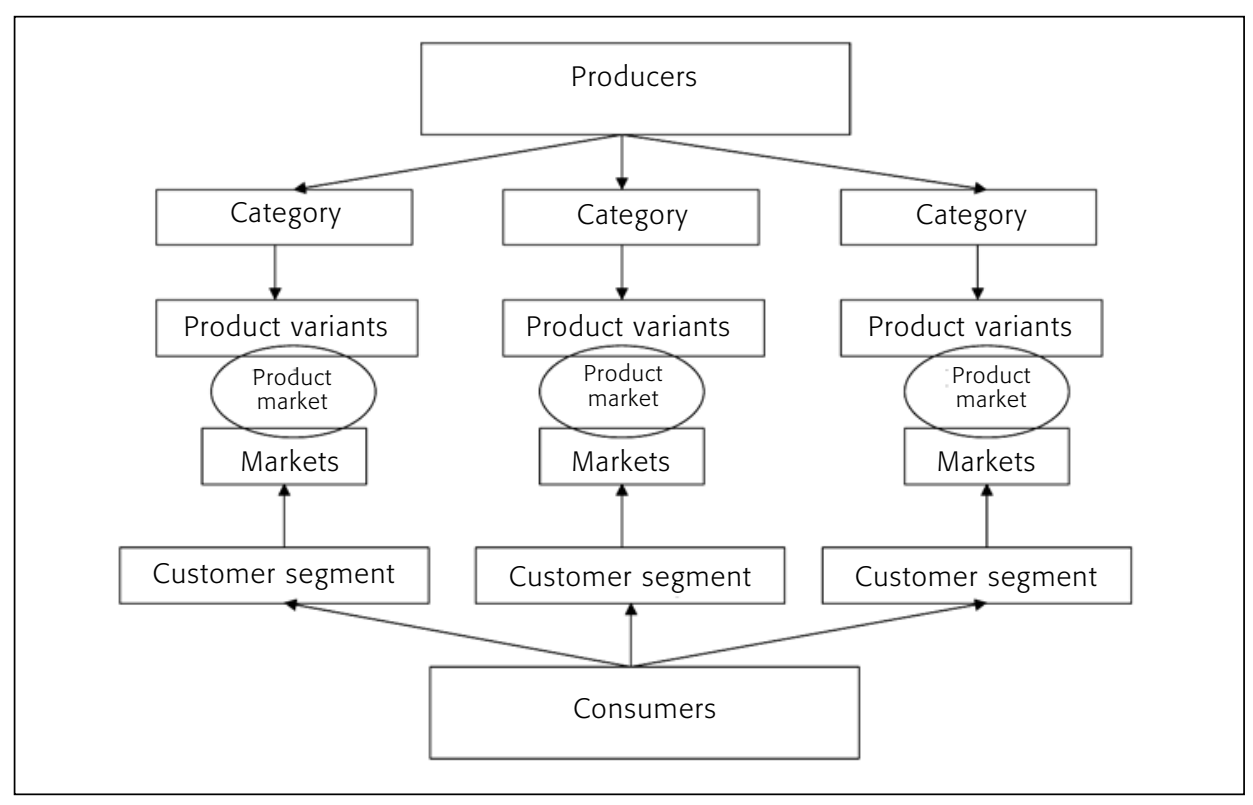




\section{Should we develop SUT?}

The answer to this must recognize that it is a 'wicked' question (Rittel and Weber, 1973) involving dilemmas and tradeoffs between competing economic, social and environmental priorities. The view taken here is that the answer to it is normative and depends on the values of the stakeholders addressing it. In many, if not all countries, it is a type of question that is answered (or avoided) by governments, or more precisely by the network of actors who contribute to debate, discussion, decision and implementation of government policy (Dredge, 2001; Hall, 1999; Pforr, 2006). This clarification recognizes that governments in many western countries have adopted a 'governance' approach to such decisions (Rhodes, 1990; 2007) where policy is developed by a network of stakeholders including the representatives of the private sector. This approach, networks of public and private sector organizations jointly developing policy (Bramwell and Rawding, 1994), is also often used in the planning and management of tourism destinations around the world. This paper argues that the decision to develop SUT is one that is dependent on development of a 'critical mass' of stakeholders with a common viewpoint amongst the network of stakeholders that are involved in policy development in a city.

Here we may identify a seeming paradox. Conceptualizing tourism as a series of overlapping product markets may seem to support the view that tourism is a fragmented sector, and indeed a tourism destination is generally considered as consisting of a fragmented and unstructured group of organizations loosely connected through networks of key stakeholders (Wang and Fesenmaier, 2007). This view has been found amongst government policy makers in both China (Airey and Chong, 2010:310) and the United States of America (Richter, 1985). Jamal and Stronza (2009:170) write that destinations 'often comprise multiple stakeholders who may hold diverse views on development and varying degrees of influence over decision making - no individual stakeholder can fully control planning'. Thus a 'useful way to approach the study and management of tourism destinations in general, and protected areas in this instance, is to view them as complex planning domains' (Jamal and Jamrozy, 2006:170).

Compounding this fragmentation, we must also consider that, from a supply side perspective, the organizations involved in tourism vary significantly in size, influence and power (Doorne, 1998; Marzano and Scott, 2009). The larger organizations are involved with customers in multiple product markets and include airports, large visitor attractions, convention centers and international hotels, as well as those involved due to organizational mandates 
such as local government councils or regional tourism organizations). It is these 'central' organizations that, often for their own purposes, become involved in policy and planning in a destination and thus address the problems of fragmentation. Hence, despite the large number of tourism businesses in a city, it has been found that there are only a limited number of 'important' organizations actively involved in tourism planning and policy in a destination as perceived by the tourism organizations themselves (Cooper, Scott, and Baggio, 2009).

Only a small number of 'key' tourism businesses in a destination are involved in policy development. A number of factors provide the rationale for this coordination. Firstly interactions between tourism businesses are necessary in providing the 'complex product that is tourism' (Palmer and Bejou, 1995:616). Secondly, the active participation by government in 'fostering the development of the tourism industry' is necessary as tourism often involves use of 'public goods' and therefore government agencies 'use a range of consultative mechanisms, formal and informal, within and between governments in order to address issues influencing industry development' (Department of Industry Tourism and Resources, 2002:89). Thus complexity and interdependency among stakeholders have resulted in the 'creation of many local tourism marketing alliances' (Palmer and Bejou, 1995:616) and other joint planning and policy activities. However, destination policy and planning activities vary in their effectiveness and may be seen as strategic or tactical in nature.

We may characterize tourism policy development as tactical or strategic and reactive or proactive. Increasingly destinations are seeking to become proactive by developing a strategic approach to planning and to proactively scan the environment, identify trends and then develop plans to address them. Such an approach may help avoid 'strategic drift' when an organization's strategy fails to address new developments in the business environment' (Johnson, 1988). This approach often begins by examining trends in the macro environment for tourism. One study using the Steep model (Steep is an acronym for Sociocultural, Technological, Economic, Environmental and Political factors) (Evans, Campbell, and Stonehouse, 2003) has identified a number of key drivers of change in Australia (Dwyer et al., 2009).

TQ, the quasi-government marketing organization for the State of Queensland in Australia has, over time, sought to develop a strategic approach to destination management and begins with the development of a vision or long term goal for the destination. Such a goal must have broad support from the stakeholders in the destination. Destination management plans bring together the marketing and development components of the tourism equation recog- 
nizing the inter-relatedness of these components and draws on a range of expertise and experience in a region. The destination plan involves the identification of core issues impacting on the growth and development of tourism in a region as well as development of a plan outlining a course of action to address these issues. A strategy to market a destination is developed in tandem and integrated as a part of the action plan formulated thus establishing a connection between tourism marketing and development planning.

\section{What are the characteristics of SUT?}

The development of sustainable urban tourism can be discussed in two ways (at least). Firstly it may be considered as a front room activity; involving the use of sustainability related innovations to attract customers. These innovations can be substantive and important for customers, or 'green wash', involving marketing but no substantial change in the product.

We may now consider the advantages of SUT taking a closer look at its characteristics and how it could be developed. SUT is tourism that is both sustainable and occurs in urban areas. The concept of sustainable tourism is fraught with difficulties in definition (Hardy, Beeton, and Pearson, 2002; Ruhanen, 2008) and practical implementation (Dodds, 2007). To avoid this debate, we consider that absolute sustainability is an ideal and that we should seek to improve the sustainability of tourism. Given this, we can consider that the concept of sustainability applies to urban tourism and indeed there are a number of studies examining SUT in Hong Kong (Jim, 2000) and the benefits of development of ecotourism products in urban areas (Higham and Lueck, 2002). We therefore accept that the concept of sustainable tourism is equally applicable in urban areas as well as rural or remote ones (Sustainable Urban Tourism, 2000).

Indeed the benefits of developing SUT include the restoration of natural areas in cities, a reduction in the impacts relating to the transportation of visitors, the ability to provide interpretation and education directed at changing attitudes and values so as to foster pro-environmental behavior to a wider range and larger number of people, both residents and tourists and, finally, improvement in the financial viability of ecotourism operations (Higham and Lueck, 2002). In addition the needs and wastes of urban tourism can be more readily planned for and managed in large numbers incorporating economies of scale. It allows for preservation of the "historic continuity of urban places so that succeeding generations of residents, as well as travelers and tourists, can 
continue to experience and sample the environmental, economic, social and cultural aspects of these places' (Savage, Huang, and Chang, 2004:224).

In considering SUT characteristics and product innovation we may also distinguish between 'front room' and 'back room' sustainability. Front room sustainability innovations include such initiatives as green maps (Dodds and Joppe, 2001), promotion of local transport use, development of walking and cycle trails (Hayes and MacLeod, 2007), and heritage preservation, cultural products and precincts (Hayllar and Griffin, 2005; Henderson, 2005). Back room sustainability innovations include use of renewable energy, recycling, the use of low impact tourism transport, and reductions in water usage. Hotels may adopt greenhouse gas reduction strategies, which benefit the environment and also result in energy savings and improved profitability for businesses (Department of Industry Tourism and Resources, 2002:81).

\section{Urban tourism}

Cities have a number of advantages for development of 'backroom' sustainable tourism; they are easily accessible as they possess airports and regular scheduled services, have a large stock of accommodation, and appeal to a number of different tourist markets by offering the services and facilities which meet a range of tourist needs (Law, 1996b).

They [cities] cater to seniors, who undertake more sightseeing and are more likely to appreciate cultural and historic heritage; young people, who are attracted by the excitement of the urban environment along with entertainment, night life and sporting events; business travelers; and the meetings, incentives, conventions and exhibition market.

Edwards, Griffin, and Hayllar, 2008:1033

A number of researchers have examined urban tourism (Maitland and Ritchie, 2009; Page, 1995) as an important type of tourism. Cities that once sold themselves to investors as places of production are now increasingly selling themselves as places of consumption (Law, 1996a). As elements of the tourism portfolio, inner-city leisure spaces, waterfront developments, festival market places, casinos, museums, conference centers and sports stadia are the physical manifestations of a wave of new local economic development initiatives for urban tourism and economic regeneration (Rogerson, 2002:170-1). Thus, cities are developing a range of infrastructure, events and destination 
brand image necessary to compete in the urban tourism product market (Dodds and Joppe, 2001).

Urban tourism also has some distinguishing characteristic in a planning and policy context; it is just

one of many economic activities within a city and it must compete with a number of other industries for resources such as labor and land. Also, within urban areas there is a complex mix of constraints on development, with natural environmental factors being generally less significant and cultural heritage and residential factors more significant than in other forms of tourism.

Edwards, Griffin, and Hayllar, 2008:1033

\section{Best practice innovations for implementing SUT}

Given that we conceptualize SUT as a type of tourism in cities that seeks to increase sustainability, what can we do to implement or improve SUT? As discussed above, any major strategic development in a tourism destination is likely to involve (at least) a group of key industry stakeholders and government. In some destinations, it will be necessary to develop such a network of stakeholders. In Queensland, an innovative, state government led, tourism stakeholder network exists as a result of a complex historical process beginning in 1920. This organization has a record of interventions or initiatives that have led to the development of a vibrant tourism sector.

The Queensland Tourist Bureau was established in 1926 and initially sold accommodation (Richardson, 1999:120) because at that time there were in Australia few travel agents as we know them today. After World War II, it was clear that wartime innovations in airplane technology would increase the potential for travel and the Queensland Government established the Queensland Tourist Development Board to determine the potential of Queensland's tourism resources. Their report outlined recommendations for the development of the state's tourist resources (Queensland Tourism Development Board, 1947), recognized limits to development, and provided a detailed analysis of the situation at that time. The report identified 20 key destinations suitable for the establishment of tourism including the capital, Brisbane, and provided for each, a description of existing access and facilities, along with suggestions for their development.

In the 1970s Australian State tourism organizations altered the emphasis of their activities to become oriented to promotion and development 
rather than to sales (Richardson, 1999:278) and the Queensland Tourist Bureau became the Queensland Tourist and Travel Corporation (QTTC) in August 1979 as a corporation, half way between government and industry (Richardson, 1999:283) to provide industry guidance. The QTTC was established under the direction of a successful businessman, Sir Frank Moore, and set about developing Queensland as a modern domestic and international tourism destination. In 1981, the QTTC sponsored a report (The Boeing Report) that provided indications of the expected level of domestic and international visitors to Queensland for 1983 and 1985 using two scenarios, a 'Natural' or 'Baseline' level of annual growth, and an 'Accelerated' level that could occur if an 'aggressive tourism posture' was adopted. These were helpful in stimulating government interest in tourism as an economic activity. QTTC also implemented a tourism survey, called the Queensland Visitor Survey, to provide statistics on the size and characteristics of the tourism industry in Queensland. The QTTC also undertook a number of other research activities and during the 1980s was arguably one of the most advanced tourism research organizations in the world thus providing credibility to its recommendations.

The QTTC implemented a number of other innovations such actively promoting the benefits of tourism to local residents, developing a network of international offices (Los Angeles, London, Tokyo, Singapore, Hong Kong, etc.), undertaking major television and film advertising both domestically and internationally, establishing a wholesale travel company (Sunlover Holidays) and other activities. The QTTC also partly funded regional tourism organizations (RTO) that deal with tourism matters in the various destinations of Queensland. This funding provides the salary of a manager in the RTO, and with other contributions obtained from tourism operators, for promotional activities. These RTO managers provide the basis for a network of destination stakeholders linked together at a state level.

The QTTC, now named TQ, however has not operated without controversy and was severely criticized in the late 1980s for a lack of concern for the environment as well as improper relationships with entrepreneurial developers (Craik, 1990; 1991). More recently, the role of TQ has focused more on marketing and promotion, resulting in the development of innovative destination branding programs (Noakes, Scott, Mallam, and Valerio, 1996) and early adoption of internet marketing strategies, most recently exemplified in the viral marketing program, "Best job in the world" (see <www.islandreefjob. com.au/about-the-best-job/>). 


\section{Innovations for SUT}

Many of the innovations introduced by TQ are useful in developing SUT or other forms of tourism. Thus, development of linkages between State, regional and local levels of tourism provides the basis for the efficient operation of a network of tourism stakeholders involved in policy development and other cooperative activity. One example of using such a network to improve destination outcomes is the creation of an agreed brand and destination image for a region which provides an important reference point for tourism development and promotion by local businesses and communities. In Queensland this destination brand and image development process was led by TQ. By defining the key attributes, assets and benefits of each region, the preferred message content, the tone and style of advertising, and facilitating the use of these attributes, a cohesive image could be communicated in all markets and the potential of the region optimized (Noakes, 2002). Based on this approach, TQ shifted from the promotion of Queensland with one destination image to the development of a portfolio of destination images. It focused promotion to Australian markets on its five developed destinations, and adopted a sophisticated consumer goods approach to tourism marketing; the first time such an approach has been applied to tourism marketing in Australia. The process involved extensive market research and industry consultation at every stage. All organizations undertaking destination marketing were involved including the RTOs, TQ, the ATC, and industry operators. Essentially this also devolved responsibility for destination marketing from the QTTC to RTOs at least in part.

A second innovation involves using the internet as a critical tool in providing visitors with the information required for trip. In Australia, a strategic initiative was developed to provide a way to ensure tourism information available was accurate and also that small tourism operators were not disadvantaged and had access to the World Wide Web. The Australian Tourism Data Warehouse (ATDW) was created through the combined effort of all Australian state and territory tourism offices, as well as Tourism Australia. It operates to provide industry with a national database of tourism products and destinations so that they can be published, promoted and sold through multiple websites and other digital media. The ATDW is the only government recognized nation-wide distribution facility for Australian tourism World Wide Web content. The database has more than 26,000 listings and 80,000 images that are quality assured and updated daily by state tourism offices to ensure accuracy and relevance to the customer who views the information. Once the tourism product listing is submitted to the ATDW national database it is then 
published through ATDW distributors who make up online tourism marketers and other digital publishers that promote tourism products and destinations through their websites. Thus the ATDW allows all tourism operators in a destination to benefit from exposure to the World Wide Web.

A third strategic innovation involved addition of a booking facility for tourism operators listed in the ATDW. ATDW distributors may also sell the tourism suppliers' inventory (rooms, tours, events, and attractions) online using ATDW's inclusive booking platform, the Tourism Exchange Australia (TXA). This allows operators to respond to the demand of travelers who would like to be able to not only read about different tourism experiences but also book them online. The TXA allows multiple booking systems to connect at the same time and sell inventory (rooms, tours, events, attractions) instantly online through ATDW's distributors. This gives the tourism supplier, the opportunity to sell rooms, tours, events or attractions online through several websites with little effort and without the trouble of phone call or email bookings. The TXA facilitates transactions made through multiple websites $(<w w w . a t d w$. com.au/>).

The introduction of the ATDW and ATX has also highlighted the lack of Information and Communication Technology (ICT) knowledge and skills of Small-Medium Tourism Enterprise (STME) managers and led to another initiative examining how SMTE managers' ICT skills can be developed. There are many published models that document how a 'typical' small business (a business with 1-20 employees for the purposes of this article) might build its website over time. Some of these are known as 'staged' website development models. Buhalis and Deimezi (2004) for example suggest that seven discrete stages in the adoption of websites may be envisaged. This development process is argued to be progressive, where the early stages of the web presence are typified by a simple 'brochure' type website, whilst later stages provide small businesses with advanced website features such as enhanced publishing opportunities, improved business promotion and interactive after sales support. At the most advanced stage, website complexity is typically reflected by having online customer order/payment processes that can mature to become fully integrated with 'back office' systems (Buhalis and Deimezi, 2004; Burgess and Cooper, 2001).

Research by McGrath (2006) indicates that there is a major or partial gap by all types of tourism service suppliers in the effective use of the World Wide Web and that the rate of adoption of ICTs in SMTEs is lower than that of larger businesses although the gap is narrowing. In a recent study in Australia (Scott et al., 2009), 41 Victorian and South Australian businesses were asked 
to identify the areas where they received their primary benefits from use of ICT. The two major areas were marketing and customer service (see table 1) although there was a reduction in the importance of marketing for less skilled managers; as a result training was considered important for managers of SMTEs. One implication of this study is that education and training is needed to foster a more innovative tourism workforce to achieve destination competitive advantage (Dwyer et al., 2009:68) and tourism firms must appreciate the importance of life-long learning and 'top-up' of skills through training. One first step is to identify operator skills through an audit and for a discussion of options for such a study see a recent paper by Scott et al. (2009). The need for training of SMTE managers in effective use of the internet has led to a series of online training modules developed by the ATDW. These and other innovations may also be of benefit in developing SUT in other parts of the world.

Table 1

Where ICTs provide most value by area

\begin{tabular}{|lcccc|}
\hline \multirow{2}{*}{ Operational area } & \multicolumn{4}{c|}{ ICT skill classification (\%) } \\
\cline { 2 - 4 } & Upper (13) & Middle (20) & Lower (7) & \\
\hline Marketing & 62 & 55 & 29 & 52 \\
Customer service & 18 & 35 & 43 & 30 \\
Finance/accounting & 8 & 10 & 29 & 13 \\
New product/service & - & - & - & - \\
development & & - & - & - \\
Supply chain & - & - & - & 3 \\
Manufacturing & 8 & 5 & - & - \\
HRM & - & 5 & - & 3 \\
Other & - & &
\end{tabular}

Source: Scott et al. (2009).

\section{Understanding existing networks}

As has been discussed above, developing strategic initiatives such as those discussed, requires a network of key policy actors to collaborate. How do we start in developing a policy network that can focus on SUT? Network Analysis (NA) can provide insights as to how a destination network can become more efficient in terms of linkage and coordination. NA provides information 
that facilitates creation of destination policy networks that can be effective in increasing the efficiency of the overall network, reducing barriers and encouraging stakeholders to share information (Wilkinson, Mattsson, and Easton, 2000). Efficient networks, which deliver competitive and sustainable destinations, can be an outcome of a NA study (Welch et al., 1998). NA provides a means of visualizing complex sets of relationships and simplifying them, and so can be useful in promoting effective collaboration within a destination actor set. It allows the identification of critical junctures in destination networks that cross functional, hierarchical, or geographic boundaries (Cross, Borgatti, and Parker, 2002). The use of standard network analysis methods enables the comparative study of the evolution and overall efficiency of destination networks.

In analyzing these systems of organizations as networks, there are three basic elements of interest: actors, relationships and resources (Knoke and Kuklinski, 1991). Firstly, actors perform activities in relationship with other actors and control network resources. These actors are of different sizes and are generally considered as highly diverse. Secondly, relationships may be considered as transactions between actors involving the transformation of resources. Such relationships are the building blocks of NA. Indeed, a network is generally defined by a specific type of relation linking a defined set of persons, objects or events (Mitchell, 1969). The resources that are exchanged among actors represent the third element of a network. These resources may include knowledge or money. Together these three elements define an actor network where the actor is linked together with all of its influencing factors to produce the network. A stakeholder's position within a destination network depends upon the number of its relationships and its role in the network (Wilkinson et al., 2000). Stakeholders gain power from their position, and, the more centrally located the stakeholder, the greater power and influence of that organization within the destination (Pavlovich, 2003). In turn, weaker organizations can develop ties with central ones to leverage benefits.

NA findings support the contention above, that all stakeholders in a destination are not perceived by others as equally salient. This finding is intuitively understandable and supports other studies that have shown differences in salience among stakeholders in destinations (Nilsson and Aring, 2007; Sheehan and Ritchie, 2005) and in the degree of involvement between stakeholder segments (Byrd and Gustke, 2007). The results of a study in Queensland indicate a moderate correlation between the perceptions of stakeholders of other's salience and their network position (Coo- 
per et al., 2009). This study found that those in the central core form an elite that is seen as more salient to destination planning, while peripheral stakeholders are seen as less important. Together the findings indicate the organization of the destination is differentiated based upon perceived salience, and suggest that destination management is controlled by a limited number of stakeholders. NA has allowed a number of structural features such as cliques, product clusters, structural divides and central organizations to be identified. The visualization of the relationships and structural positions of stakeholders makes the approach especially useful as the structures can be easily understood by managers and communicated to the destination stakeholders.

\section{Conclusions}

SUT seeks to reduce tourism's impact on the global environment, sustain the local environment and to cater to both the host community and visitors. The notion of SUT also implies a desire to seek a more productive and harmonious relationship among visitors, host communities and the environment (Savage et al., 2004), whether natural or in urban settings. A number of characteristics of SUT have been discussed above, and based on this discussion, it has been suggested that in an urban setting both 'front room' and 'back room' sustainability be encouraged in order to move towards sustainability. Developing SUT is an important and strategic objective and requires the collaboration of a network of destination stakeholders. It is contended here that use of NA techniques can illuminate the nature of tourism networks and hence provide the basis for improvements in policy development effectiveness.

This article has also provided a number of strategic initiatives used in Australia for improving tourism in general. These include development of robust organizational structure that facilitate innovation, implementation of integrated destination branding and image, and improving the ability of SMTEs to access the World Wide Web. These initiatives may be use in other destinations around the world in improving or developing SUT. One place to start in the development of SUT is a NA study of the structure of the tourism in a destination and this provides a logical area for further research. 


\section{References}

AIREY, D.; CHONG, K. National policy-makers for tourism in China. Annals of Tourism Research, v. 37, n. 2, p. 295-314, 2010.

BRAMWELL, B.; RAWDING, L. Tourism marketing organizations in industrial cities: organizations, objectives and urban governance. Tourism Management, v. 15, n. 6, p. 425-434, 1994.

BUHALIS, D.; DEIMEZI, O. E-tourism developments in Greece: information communication technologies adoption for the strategic management of the Greek tourism industry. Tourism and Hospitality Research, v. 5, n. 2, p. 103-130, 2004.

BURGESS, L.; COOPER, J. The adoption of the Web as a marketing tool by Regional Tourism Associations (RTAs) in Australia. In: AUSTRALIAN CONFERENCE ON INFORMATION SYSTEMS, 12., 2001.

BYRD, E. T.; GUSTKE, L. Using decision trees to identify tourism stakeholders: the case of two Eastern North Carolina counties. Tourism \& Hospitality Research, v. 7, n. 3/4, p. 176-193, 2007.

COOPER, C.; SCOTT, N.; BAGGIO, R. The relationship between network position and perceptions of destination stakeholder importance. Anatolia, v. 20, n. 3, p. $33-45,2009$.

CRAIK, J. A classic case of clientelism: the Industries Assistance Commission inquiry into travel and tourism. Culture and Policy, v. 2, n. 1, p. 29-45, 1990.

. Government promotion of tourism: the role of the Queensland Tourist and

Travel Corporation. Brisbane: Centre for Australian Public Sector Management, Griffith University, 1991.

CROSS, R.; BORGATTI, S. P.; PARKER, A. Making invisible work visible: using social network analysis to support strategic collaboration. California Management Review, v. 44, n. 2, p. 25-46, 2002.

DAY, G. S.; SHOCKER, A. D.; SRIVASTAVA, R. K. Customer oriented approaches to identifying product-markets. Journal of Marketing, v. 43, n. 4, p. 8-19, 1979.

DEPARTMENT OF INDUSTRY TOURISM AND RESOURCES. The 10 year plan for tourism: a discussion paper. Canberra: Department of Industry, Tourism and Resources, 2002.

DODDS, R. Sustainable tourism and policy implementation: lessons from the case of Calvia, Spain. Current Issues in Tourism, v. 10, n. 4, p. 296-322, 2007.

; JOPPE, M. Promoting urban green tourism: the development of the other map of Toronto. Journal of Vacation Marketing, v. 7, n. 3, p. 261-267, 2001. 
DOORNE, S. Power, participation and perception: An insider's perspective on the politics of the Wellington waterfront redevelopment. Current Issues in Tourism, v. 1, n. 2, p. 129-166, 1998.

DREDGE, D. Local government tourism planning and policy-making in New South Wales: institutional development and historical legacies. Current Issues in Tourism, v. 4, n. 2-4, p. 355-380, 2001.

DWYER, L. et al. Destination and enterprise management for a tourism future. Tourism Management, v. 30, n. 1, p. 63-74, 2009.

EDWARDS, D.; GRIFFIN, T.; HAYLLAR, B. Urban tourism research: developing an agenda. Annals of Tourism Research, v. 35, n. 4, p. 1032-1052, 2008.

EVANS, N.; CAMPBELL, D.; STONEHOUSE, G. Strategic management of travel and tourism. Oxford: Butterworth-Heinemann, 2003.

FROCHOT, I.; MORRISON, A. Benefit segmentation: a review of its applications to travel and tourism. Journal of Travel and Tourism Marketing, v. 9, n. 4, p. 21-45, 2000 .

GALLOWAY, G. et al. Sensation seeking and the prediction of attitudes and behaviours of wine tourists. Tourism Management, v. 29, n. 5, p. 950-966, 2008.

GOSSLING, S.; PEETERS, P. 'It does not harm the environment!' An analysis of industry discourses on tourism, air travel and the environment. Journal of Sustainable Tourism, v. 15, n. 4, p. 402-417, 2007.

HALL, C. M. Rethinking collaboration and partnership: a public policy perspective. Journal of Sustainable Tourism, v. 7, n. 3-4, p. 274-289, 1999.

HARDY, A.; BEETON, B.; PEARSON, L. Sustainable tourism: an overview of the concept and its position in relation to conceptualisations of tourism. Journal of Sustainable Tourism, v. 10, n. 6, p. 475-496, 2002.

HAYES, D.; MACLEOD, N. Packaging places: designing heritage trails using an experience economy perspective to maximize visitor engagement. Journal of Vacation Marketing, v. 13, n. 1, p. 45-58, 2007.

HAYLLAR, B.; GRIFFIN, T. The precinct experience: a phenomenological approach. Tourism Management, n. 26, p. 517-528, 2005.

HENDERSON, J. C. Planning, changing landscapes and tourism in Singapore. Journal of Sustainable Tourism, v. 13, n. 2, p. 123-135, 2005.

HIGHAM, J.; LUECK, M. Urban ecotourism: a contradiction in terms? Journal of Ecotourism, v. 1, n. 1, p. 36-51, 2002. 
JAMAL, T.; JAMROZY, U. Collaborative networks and partnerships for integrated destination management. In: BUHALIS, D.; COSTA, C. (Eds.). Tourism management dynamics. trends, management and tools. Oxford: Elsevier Butterworth-Heinemann, 2006. p. 164-172.

; STRONZA, A. Collaboration theory and tourism practice in protected areas: stakeholders, structuring and sustainability. Journal of Sustainable Tourism, v. 17, n. 2, p. 169-189, 2009.

JIM, C. Environmental changes associated with mass urban tourism and nature tourism development in Hong Kong. The Environmentalist, v. 20, n. 3, p. 233-247, 2000.

JOHNSON, G. Rethinking incrementalism. Strategic Management Journal, v. 9, n. 1, p. 75-91, 1988.

JUROWSKI, C.; REICH, A. Z. An explanation and illustration of cluster analysis for identifying hospitality market segments. Journal of Hospitality and Tourism Research, v. 24, n. 1, p. 67-91, 2000.

KELLY, J.; WILLIAMS, P. W. Modelling tourism destination energy consumption and greenhouse gas emissions: Whistler, British Columbia, Canada. Journal of Sustainable Tourism, v. 15, n. 1, p. 67-90, 2007.

KNOKE, D.; KUKLINSKI, J. H. Network analysis: basic concepts. In: THOMPSON, G. et al. (Eds.). Markets, hierarchies and networks. London: Sage Publications, 1991. p. 173-182.

LAMBKIN, M.; DAY, G. S. Evolutionary processes in competitive markets: beyond the product lifecycle. Journal of Marketing, v. 53, n. 3, p. 4-20, 1989.

LAW, C. M. Introduction. In: (Ed.). Tourism in major cities. London: International Thomson Business Press, 1996a. p. 1-22. 1996b.

. Tourism in major cities. London: International Thomson Business Press,

MAITLAND, R.; RITCHIE, B. City tourism: national capital perspectives. Australia: University of Queensland, 2009.

MARZANO, G.; SCOTT, N. Power in destination branding. Annals of Tourism Research, v. 36, n. 2, p. 247-267, 2009.

MCGRATH, G. M. The identification of ict gaps and needs within the Australian tourism industry. Information Technology in Hospitality, n. 4, p. 161-178, 2006.

MCKERCHER, B.; CHAN, A. How special is special interest tourism? Journal of Travel Research, n. 44, p. 21-31, 2005. 
MITCHELL, J. C. The concept and use of social networks. In: (Ed.). Social networks in urban situations. Manchester: University of Manchester Press, 1969. p. 1-50.

NILSSON, P.; ARING, K. Stakeholder theory: the need for a convenor. The case of Billund. Scandinavian Journal of Hospitality and Tourism, v. 7, n. 2, p. 171-184, 2007.

NOAKES, S. Rejuvenating a maturing tourist destination: the case of the Gold Coast. Current Issues in Tourism, v. 5, n. 6, p. 474-513, 2002.

et al. The branding of Far North Queensland. Cairns: Far North Queensland Promotion Board, 1996.

PAGE, S. J. Urban tourism. London: Routledge, 1995.

PALMER, A.; BEJOU, D. Tourism destination marketing alliances. Annals of Tourism Research, v. 22, n. 3, p. 616-629, 1995.

PAVLOVICH, K. The evolution and transformation of a tourism destination network: the Waitomo Caves, New Zealand. Tourism Management, v. 24, n. 2, p. 203-216, 2003.

PFORR, C. Tourism policy in the making: an Australian network study. Annals of Tourism Research, v. 33, n. 1, p. 87-108, 2006.

QUEENSLAND TOURISM DEVELOPMENT BOARD. The tourist resources of Queensland and the requirements for their development. Brisbane: Queensland Tourism Development Board, 1947.

READ, S. E. A prime force in the expansion of tourism in the next decade: special interest tourism. In: HAWKINS, D. E.; SHAFER, E. L.; ROVELSTAD, J. M. (Eds.). Tourism marketing and management issues. Washington DC: George Washington University, 1980.

RHODES, R. Policy networks: a British perspective. Journal of Theoretical Politics, n. 2, p. 293-317, 1990.

. Understanding governance: ten years on. Organization Studies, v. 28, n. 8, p. 1243-1264, 2007.

RICHARDSON, J. I. A history of Australian travel and tourism. Melbourne: Hospitality Press, 1999.

RICHTER, L. K. Fragmented politics of US tourism. Tourism Management, v. 6, n. 3, p. 162-173, 1985.

RITTEL, H.; WEBER, M. Dilemmas in a general theory of planning. Policy Sciences, v. 4, n. 2, p. 155-169, 1973.

ROGERSON, C. M. Urban tourism in the developing world: the case of Johannesburg. Development Southern Africa, v. 19, n. 1, p. 169-190, 2002. 
ROSA, J. A. et al. Sociocognitive dynamics in a product market. Journal of Marketing, v. 63, n. 4, p. 64-77, 1999.

RUHANEN, L. Progressing the sustainability debate: a knowledge management approach to sustainable tourism planning. Current Issues in Tourism, v. 11, n. 5, p. 429-455, 2008.

SAVAGE, V. R.; HUANG, S.; CHANG, T. C. The Singapore River thematic zone: sustainable tourism in an urban context. The Geographical Journal, v. 170, n. 3 , p. 212-225, 2004.

SCOTT, N. Trends in tourism: evolution of tourism product markets. In: CAUTHE CONFERENCE, 5-8th Feb., Coffs Harbour, 2003.

et al. Development of a toolkit designed to guide SMTEs in planning for and implementing ICT within their enterprises. Gold Coast: STCRC, 2009.

SHEEHAN, L.; RITCHIE, J. R. B. Destination stakeholders: exploring identity and salience. Annals of Tourism Research, v. 32, n. 3, p. 711-734, 2005.

SUSTAINABLE URBAN TOURISM. Sustainable urban tourism - governance project. 2000. Sourced <www. sut.itas.fzk.de/>.

VARGO, S. L.; LUSCH, R. F. Evolving to a new dominant logic for marketing. Journal of Marketing, n. 68, p. 1-17, 2004.

. Service-dominant logic: continuing the evolution. Journal of the Academy of Marketing Science, v. 36, n. 1, p. 1-10, 2008.

VISWANATHAN, M.; CHILDERS, T. L. Understanding how product attributes influence product categorization: development and validation of fuzzy set-based measures of gradedness in product categories. Journal of Market Research, n. 36, p. 75-94, Feb. 1999.

WANG, Y.; FESENMAIER, D. R. Collaborative destination marketing: a case study of Elkhart county, Indiana. Tourism Management, v. 28, n. 3, p. 863-875, 2007.

WEILER, B.; HALL, C. M. (Eds.). Special interest tourism. London: Belhaven Press, 1992.

WELCH, D. E. et al. The importance of networks in export promotion: policy issues. Journal of International Marketing, v. 6, n. 4, p. 66-82, 1998.

WILKINSON, I. F.; MATTSSON, L. G.; EASTON, G. International competitiveness and trade promotion policy from a network perspective. Journal of World Business, v. 35, n. 3, p. 275-299, 2000.

WTO (World Tourism Organization). Tourism highlights 2009. Madrid: WTO, 2009. 